\title{
Superficial biopsy of the cervix: new technique
}

\author{
by \\ Ettore De Girolami * \\ (Manuscript Received April 25, 1953)
}

The cytological examination of secretions in the vagina an $i$ cervix of the female is the most common of all cytological studies (4). The technique consits of preparing a smear taken directly from external os of the cervix uieri or from the posterior fornix of the vagina, smearing the secretion on a slide and subsequent fixation and study. This method of examination offers the following advantages:

a) It is not traumatic.

b) All the cells constituting the anatomical parts are represented.

c) The vaginal secretion can be examined even though there is infection in the uterus which would interdict a formal biopsy (3).

d) It changes in no way the clinical picture.

e) When no neoplasm is found it is often possible to diagnose horriona! malfunction.

In the study of cancer of the cervix uteri, the neoplasm of lighest inctdence in women, it has been found that these tumors originate in the scliamo-columnar junction of the cervix. AYRE (1) has shown that the best methou for cell study of preclinical cervical cancer is to scrape with a wooden spatula the cells of squamocolumnar junction. This method, called, the superficial biopsy, involves examination of cervical epithelium of that area scraped by the spatula and has the advantage over examination of vaginal secretions of not containing mucous which makes cell study difficult. The biopsy for cervical cancer has the disadvantage that, although a part is taken that clinically seems the most suspicious,

* From Department of Histology, University of Costa Rica, School of Sciences, and from

Costa Rican Department of Cancer Prevention. 
it may mis the malignant area. The superficial biopsy, however, affords the nportunity of making a more complete study of cells which compoce the squidmocolumnar region.

In our Tumor Clinic we have been doing diagnostic cytologic smear examinations for some time routinely on all patients using superficial biopsy technique. We are especially interested in those patients who come to the Clinic with other that gynecologic complaint. We have thus diagnosed several operable cancers of cervix uteri which would have otherwise remained latent. At present it is too early to evaluate the cases statistically but we will do so in the near future.

Our Clinic attends Charity patients only and funds are limited. Because of the high cost of the Papanicolaou technique, which according to CUYLER (2) amounts to $\$ 0.90$ per examination, we have been using the following tecinrique with good results.

Clean the vagina thoroughly with dry gauze then introdice an applicator stick into the external os of the cervix uteri and revolve it cloch-wise scraping or abrading the epithelium. The material thus obtained should be spread on a glass slide immediately revolving the stick clock-wise while doing so. Next color by Giemsa method. The applicator should be made by wrapping a piece of gauze on an applicator stick forming a bulky tip which will fit the os snugly. The tip should be moistened in the following solution immediately before insing: to fix the cellis as soon as they are scrapedoff.

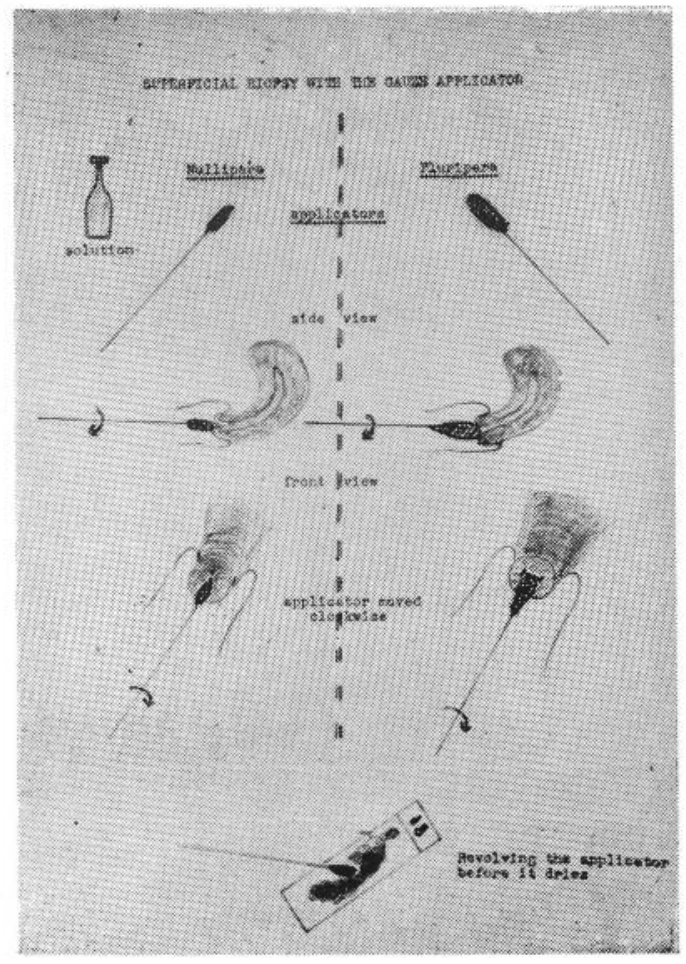

Fig. 1. 


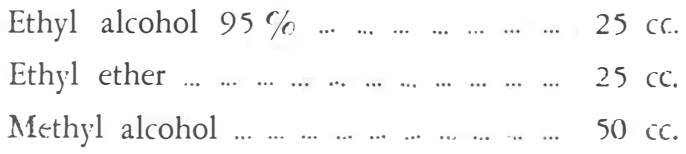

This system offers the following advantages:

a) Mucus which would hinder cellular study is removed.

b) The gauze has the same scraping effect as the wooden : patula ani tissues adhere better to it.

c) Cells are fixed at the time they are taken since the graze has been moistened in a fixing solution.

d) The simple applicator can be prepared easily.

e) Low cost.

f) Using the Giemsa stain the cells can be colored directly since the cells have been previously fixed.

The cells in the smear are gathered closely thus forming pseudo-tissues which makes microscopic study much easier (Fig. 2).

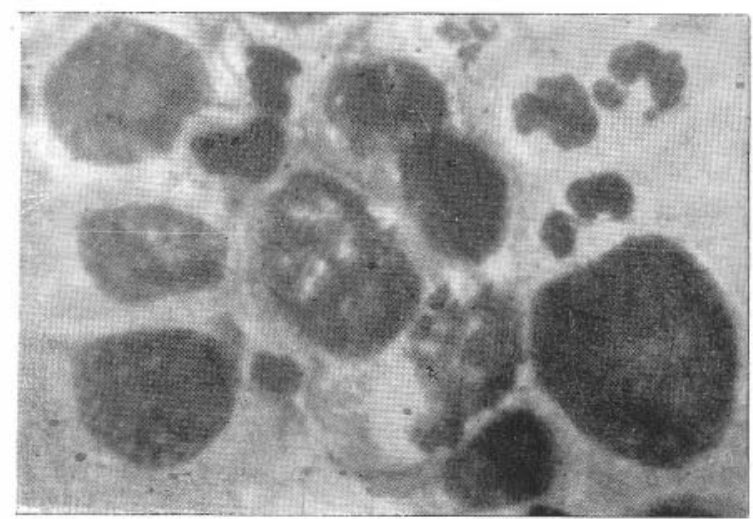

Fig. 2.-Cluster of malignant cells forming pseudo-tissues

In the early diagnosis of cancer it does not suffice to visualize the harac. teristics of malignant cell, but also to study the technique for preparation of smear.

The described procedure has the object of simplifying the study of cells and, with immediate fixation, will permit the examination of cells as far possible similar to those of living tissues. 


\section{SUMMARY}

Cytological examination of the cervix in all patients is considered a necessity. A new technique of superficial biopsy is described and advantages ennumerated.

\section{RESUMEN}

El Autor presenta una nueva técnica para biopsia superficial, considerando la necesidad de hacer rutinariamente a todas las pacientes el examen citológico del cérvix. La muestra se toma con el extremo de un aplicador cubierto de gaza. Este dispositivo, humedecido previamente en una solución de etanol, metanol y éter etílico, se aplica inmediatamente al cérvix del útero y, dándole un movimiento como el de las manecillas del reloj, se toma la muestra con la cue se hacen frotis por aposición que se colorean por el método de Giemsa.

Esta técnica of rece la ventaja de que el tejido en estudio se adhiere perfectamente a la gaza, la cual, con el movimiento de rotación, desorende las células del "os uteri", las que son fijadas al mismo tiempo. La preparación dei dispositivo es sumamente sencilla. La prueba resulta de bajo costo como de breve y fácil realización.

\section{RIASSUNTO}

L'Autore prende in considerazione l'utilitá dell'esame citologico del collo dell'utero, fatto rutinariamente a tutte le pazienti.

Si descrive una nuova tecnica di biopsia superficiale che oltre ad of frire dei vantaggi é di poca spesa e si puó eseguire con facilitá ed in breve tempo.

\section{REFERENCES}

1. AYRE, J. E.

1947. Selective cytology smear for diagnosis of cancer. Amer. Jour. Obst. E Gynec. 53:609- 617 .

2. Cuyler, W. K., Kaufmiann, L. A., Carter, B., Ross, R. A., Thomas W. L. \& Palumbo, L.

1951. Genital cytology in obstetric and gynecologic patients. A four-year study. Amer. Jour. Obst. E Gynec. 62 (2):263- 278.

3. Guidoux, A.

1947. Diagnostic précose du cancer utérin. Presse Med. 32:358-359.

4. Staff of Vincent Memorial Laboratory.

1950. The cytologic diagnosis of cancer. xiii. +229 pp. W. B. Saunders, Philadelphia. 